\title{
色彩の知覚と光の心理効果*
}

\section{大山 正**}

\section{Perception of colors and their psychological effects}

\author{
Tadasu Oyama
}

\section{1. 光線には色がついていない——色彩は感覚である}

The Rays are not coloured とはニュートンが，その 著『光学一光の反射, 屈折, 回析，および色に関する 論述』(1704)中で述べている言葉である.色の科学的研 究はニュートンに始まるといってよいであろう。彼がプ リズムを用いて太陽の光を 7 色のスペクトルに分散させ たことは余りにも有名であるが，彼が分散したスペクト ル光をレンズとプリズムを用いて集光して，再び白色の 光に戻す実験をしたことはそれほど知られていない．彼 は更に，その際，スペクトル中の光をスリットを用いて 選択して通過させ，その一部の光のみをレンズで集光さ せることによって混色 color mixture の実験を行ってい る．例えばスペクトル中の赤光と緑光を集光させるとあ ざやかな黄の光ができる．しかし，これは，スペクトル 中の黄色部分と物理的に異質なものであることは，第 3 のプリズムを通すことによって確めることができる．混 色で出来た黄光は再び赤と緑の光に分散するが，スペク トル中の黄光は何度プリズムを通しても分散しない.

ニュートンは，このような混色実験の結果に基づいて， 光線と色とを区別し, 色は感覚であり, 光線の性質では ないことを「光線には色がついていない」という言葉で 表した. 彼は，赤い光，青い光という呼び方は不適当で， 正確には，赤をつくる光線（Red-making Ray）青をつ くる光線などと呼ぶべきであると強調している．彼は, 光線と色の感覚の関係を空気の振動と音の感覚の関係に たとえ，その区別を明確に論じている.

赤, 緑, 青の3色の光の混合によってほとんどすべての 色がつくり出せることは, その後の厳密な定量的研究に よって確められている.(浪とえどすべての色と言ったの は, 青緑など一部の色は混色では鮮やかさが不十分とな るからである.)この混色の事実が今日の色彩科学の基礎 となっている.すなおち, 色賞の3色説, $\mathrm{RGB} \cdot \mathrm{XYZ}$ 表色 系, 3 色信号によるカラーテレビ・システム等の基本とな ている.ただし，3色混合によって，他のさまざまの色と 等色するのは, 正常色賞の性質であり, 色賞異常者では 2 色の混合で他のさまざまの色と等色できる場合がある.

* 原稿受付 1996 年 9 月 30 日

** 日本大学文理学部心理学科

\section{2. 色の 3 属性}

\section{1 色相・明るさ・飽和度（彩度）}

スペクトルの光は，波長に応じて，董から赤までに変 化する。このような色の違いを色相とよぶ．スペクトル の両端の董と赤の光を混色すると紫が生じる.この紫は, スペクトル中にはない色で，董または青の光と赤の光の 混合で生じ, 混合の比率に応じて, 青紫から赤紫までに 色相が変化する．ところでこの紫を間に置くと，スペク トルの両端の色相は比較的似ていることに気づかれる。 堇は青にやや赤みが加わった色である．スペクトルの 7 色に，スペクトル外の紫を加えると，それらの色相を円 環状に並べることができる。これが, 色円 color circle と いわれるものである. 赤, 橙, 黄, 緑, 青, 藍 (紫青), 董 (青紫)，紫，と循環して赤にもどる．こう並べると色 相が次第に連続して変化していることに気づく.

また，どの色相でも，色相が一定のままで明るさが変 化した色がある. 光の色であれば，鮮やかさもほ沽一定 のまま，光の強度に応じて明るさが変化する．物体の色 の場合は，明るさが変わるとともに，鮮やかさも変化す る，たとえば，赤では，明るく鮮やかな赤い物体色とか， 暗く鮮やかな赤の物体色は存在しない. 非常に鮮やかな 赤は中程度の明るさに限られる．同様に，最も鮮やかな 黄㳉るく，もっとも鮮やかな紫はかなり暗い。これは, 人間の眼の視感度とも関連している，なお物体色の明る さは，しばしば明度ともよばれる。

飽和度 saturation また彩度とは, 色の鮮やかさを示し ている. スペクトル中の単色光に白色光を混合すると, 一般に, 飽和度が低下する。飽和度にほほ対応する刺激 変数は, 純度（正確には輝度純度 colorimetric purity, p)である。これは，混合光の輝度中の単色光の輝度成分 の比率を示している.

$$
p=L_{\lambda} /\left(L_{w}+L_{\lambda}\right)
$$

ここで $L_{w}, L_{\lambda}$ はそれぞれ混合する白色光と単色光の輝 度を示している。

一般に，色は，以上に述べた，色相，明るさ，飽和度 の 3 つの次元に沿って変化する．これらを色の 3 属性と よぶ.これらの 3 属性のうち色相は波長に, 明るさは輝 
度また反射率に，飽和度は純度に，というようにそれぞ れ刺激の特性にほほ対応しているが，その対応関係は完 全ではない.スペクトルの青緑領域と橙領域では同一波 長でも高輝度となると青味または黄味を帯びやすく，低 輝度では緑味または赤味を带びやすい傾向を示す。この ベツォルト・ブリュッケ現象は, 輝度が変わると波長と 色相の対応関係が変わってくることを示している．また 純度が変わっても, 波長と色相の対応関係が変わってく る.これをアブニー効果という.

\section{2 色立体}

色相を円，明るさをその円の中心を垂直に貫く軸，飽 和度を円の中心からの距離で表わすと, 円筒座標系に よってすべての色を 3 次元空間中で配置することができ る.これを色立体 color solid と呼ぶ. 口絵 1 に示す, 、 ンセルの考案した色立体はその代表的な例である. 主と して物体色を表わすのに用いられる.色相 hue, 明度 value, 彩度 chromaをもって示される. 色相は, 赤

$(\mathrm{R})$, 黄赤 (YR) (ほほ橙に相当), 黄 $(\mathrm{Y})$, 緑黄 (GY) 緑 $(G)$, 青緑 (BG), 青 (B), 紫青 (PB)（注董に相 当), 紫 $(P)$, 赤紫 $(R P)$ の 10 色相が円環状に並び, さ らに，それぞれ 10 等分される.JIS（日本工業規格）に も採用されているが, JIS では緑黄でなく黄緑, 紫青を青 紫とよぶ．ただし記号は GY，PBのままである。

口絵 1 のように，このマンセル色立体を放射状に切っ た垂直断面上には，同一の色相をもつさまざまな色が並 ぷ, 上部に行くほど明度が高く, 中心よりはなれるほど 彩度が大となる，同じ色相，同じ明度で彩度のみが異な る色が，同じ高さに水平に並ぶ．また同じ色相，同じ彩 度で明度のみ異なる色が垂直に並ぶ。

\section{3 感賞尺度}

以上に述べた色相, 明るさ, 飽和度（彩度）は, おお まかに言えぱ, 光の波長, 光の強度 (輝度), 純度に対応 するが, その数量的対応関係は単純な線型関係ではない. そこで感覚の量的変化を適切に表す感覚尺度作成の問題 が生じる.第 1 の光の強度と明るさの間には,フェヒナー の対数法則やスティーヴンスのべき法則の適用が試みら れている.第 2 の波長と色相の間の関数関係は複雑であ り, 単純な数式では表わせられない. 目で見て色相の差 が区別できる最小の限界，すなわち弁別閾（いき）の值 は弁別条件によっても，波長領域によっても異る．好条

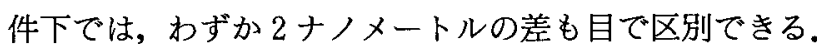
弁別しやすい波長領域は，420，470，570ナノメートル付 近で色相の変換点に相当し, 青, 緑, 赤などの主要色相 のそれぞれの波長領域の中央部分では一般に弁別が悪く なる、スペクトルに各主要色相がしめる幅も一定してい ない. 緑や赤は幅広く, 黄では幅せまい. 第 3 の純度と 彩度の間の数量的関係についても, べき関数などの関数 関係が提案されている.

前述のマンセル色立体では, 結果的に色相, 明度, 彩 度の変化がほほ等歩度になるように経験的に等度が決め
られて, XYZ 系色度座標 (内川論文参照) との関係が数 值化されている。

\section{3.色の見元方}

標準的な状態で観察すれば，光や物の色は，波長，純 度, 輝度などから予想されるような色相, 飽和度, 明る さに見えるが，色の見え方はそれらの刺激変数によって 一義的に決まるわけではない。観察者側の条件や刺激側 の時間・空間的条件により，色の見方方は種々変化する. また，色残像のように，その時点ではまったく外部から の視覚刺激がなくても，色が見える場合すらある．以下 では色の現れ方の分類と色の見え方を規定する重要な要 因である色順応と色の対比について述べよう。

\section{1 色の現れ方}

同じ青でも, 布の青と, 空の青, 液体の青, 色ガラス の青などでは，それぞれ現れ方が異なる。カッツは次の ような現れ方 (mode of appearance) の種類を挙げてい る.

（1）面色 (film color) : 青空の色や光学器械中の色の 現れ方. 距離感が不確定で, 視線に垂直にひろがり, か たい表面は感じられず，やわらかく，突き入ることがで きる印象を与えるが, 3 次元的な奥行きはなく，ほ涩平面 的である。衝立の小穴などを満たす色がこの面色で現れ るので, 開口色 (aperture color) とよばれることもあ る.

（2）表面色（surface color）：色紙や通常の不透明の 物体の表面の色で, 距離感は確定的で, 表面は硬く, 視 線に対してさまざまの傾きと曲面をも示す．表面色の色， 明るさは照明の色, 明るさと分離して知覚できる. 色と 明るさの恒常性（照明の色や強度が変わっても, 物の色 や明るさがほほ一定に知覚される傾向）が成立する. 物 体色 (object color) ともよばれる.

（3）透明面色（transparent film color）：色ガラスゃ 回転中の扇風機の羽根を通して他の物体を見るとき，背 後の物体の色は定位の確立した表面色に見え, 色ガラス や回転中の扇風機の羽根の色は定位の不確かな面色とし てかつ透明に見える。これを透明面色という。

（4）透明表面色 (transparent surface color)：両眼で 本を読んでいる際に, 片眼の前に手を邨くと, 手を通し て本の印刷された文字が見える. その際, 手の表面の色 は明確な定位をもつ表面色で，かつ透明に見える。これ を透明表面色という。

（5）空間色 (volume color): ガラス器の中の着色液体 の色のように空間に拡がった色.

（6）鏡映色 (mirrored color)：みがかれた床や水面に 他の対象が映っている場合の対象の色. 床や水面の色の 背後に現れる。

（7）光沢 (luster): 通常, 表面色に囲まれ，それょり ずっと明るい部分に現れる。両眼にうつる明るい部分の 位置が互いにずれているときに，光沢感が顕著である。 
（8）光輝 (luminosity)：みずから光を発しているよう な見え方．周囲より輝度が高い必要があるが，実際に光 を発している必要はないことは，レンブランドの作品の ように絵画によって光輝が示せることでもわかる.

(9) 灼熱 (glow): 溶解した鉄や電気ストーブのニクロ ム線のように，表面だけでなく，内部からも光を発して いるような印象の色の現れ方.やわらかく，つきとおせ る感じを与える。

\section{2 色順応}

同じ色をつづけて見つめていると，その色の飽和度が 次第に減少してゆき，その後，視野の同じ場所に他の色 を提示すると，通常とは異なった色に見える。この現象 を色順応 (color adaptation) とよぶ. 色順応の過程にお いて, 飽和度 (彩度) は, はじめ急激に, その後次第に ゆるやかに低下していくが，色味を完全に失って無彩色 になるようなことはなかった。

色順応下では，物の色の見え方が，全般的に変って見 える。ある色をもつ照明下にしばらく居ると, 目はその 色に順応する，照明色と同じ色の光を反射する物体が白 色に見えるようになり，通常は白色に相当する一様な分 光分布の光を反射する物体は，かえって照明光の色の補 色に色づいて見える. 白色の物体をその照明下におくと， 照明光の色光を反射するが，目の色順応のため，白色に 見える，その他の色の物体も，色照明下では反射する光 の分光分布が変ってくるが，見かけの色はそれほど変ら ない. 色の恒常性 color constancy である. 白熱電灯と蛍 光灯では分光分布が大きく違うが，それぞれの照明下で の物体の色の見え方はそれぼ゙違わないのは，そのため である.色づいたサングラスをかけた場合も色順応が生 じ，色の恒常性が成立する.

\section{3 色の対比と同化}

灰色の小片を赤色の背景の上におくと淡く緑色を帯び, 青色の背景の上におくとほのかに黄に色づく, (口絵 2 参 照).また，色のついた小片を，それと異なった色相の背 景の上においた場合も，色がやや変わって見える．多く の場合，背景の補色の色が加わって見える。これらの現 象を色の対比 color contrast とよぶ, 色の対比にも, こ の例のような同時対比とともに継時対比もある.しかし， 継時対比は上述の色順応のひとつの現われともいえるか ら, 以下では同時対比についてのみ述べる.

色の対比については，キルシュマンの法則としてつぎ の 5 項目が提出されている.

（1）誘導領域に比べて検查領域が小さいほど色の対比は 大きい.

(2) 色の対比は, 誘導・検查両領域が空間的に分離して いても生じるが，その空間間隔が大きくなるほど対比 効果が隇少する。

（3）誘導領域が大きいほど対比効果は大きくなる.

（4）明るさの対比が生じないか，あるいは最小のときに, 色の対比は最大となる。
（5）明るさが等しいとき, 誘導領域の飽和度が大きいほ ど対比も大となる.

ここで, 誘導領域とは, 上例の色のついた背景に相当 し，検查領域とは，その上におかれた小片に相当する.

ここに述べられた 5 項目は大部分, その後の実験的研 究によって確認されているが，(4)については否定的の結 果が得られている。 むしろ, 明るさの対比が大なるとき に，色の対比も大になる傾向が認められている.

色の対比は, 一般に, 周囲の色の差を強調するように 働くが，口殓 3のように色の縞が描かれた灰色部分が， 縞の色に近付いて兒えることがある.これを色の同化 color assimilation という.細い縞が反復する際に生じや すい.

\section{4 主観色}

主観色（subjective color）とは, 客観的には色はな く，白と黒のパターンにすぎないものが色づいて見える というので, この名がある。精神物理学の創始者である フェヒナーがすでに研究していたので, フェヒナー色と もいう，有名なのは，図１のようなベンハム(Benham) のこまである。このような円盤を回転させると，適当な 回転速度の場合に，円弧の間の部分に淡い色が現われ， 中心からの距離に応じてその色相が変わる。この種の主 観色はいろいろな模様の円盤で観察することができる. 白黒テレビの受像器の同期をはずした場合にも同じよう な色を観察できる.これは，眼に到達する光は全く波長 の偏りがない白色光であっても, その時間空間的パター ンによって，色が見える例である。

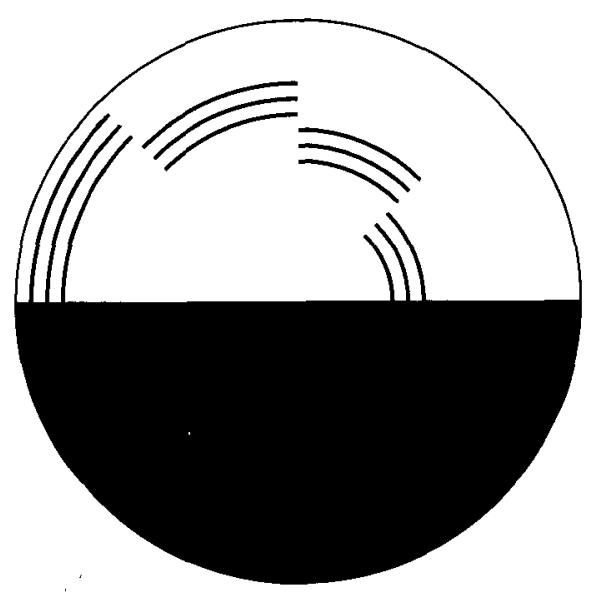

図 1 ベンハムのこま

\section{4. 色賞説}

以上述べて来たような色党の基礎となるメカニズムに 関する学説としてはヤング・ヘルムホルツの 3 色説 Young-Helmholtz trichromatic theory とヘリングの 反対色説 Hering opponent-color theoryがよく知られ ている。 


\subsection{3 色説}

3 色説によれば, 網膜中には 3 種の錐体があり,それぞ れ, 長 (赤), 中 (緑), 短 (青) の波長領域の光に感度 が高く，それぞれの錐体が伝える興奮の大きさの比率関 係によって，さまざまの色の感覚が生じるとされる。 そ のうちの 1 種の錐体がもっぱら興奮し，他の 2 種が注と んど興奮しなければ, 当然, 赤, 緑, または青の感覚が 生じる.また, 2 種の錐体が同程度に興奮し, 他の 1 種が あまり興奮しなければ, 黄, 青緑, または紫の感覚が生 じる.たとえば, スペクトルの黄の部分の光が目に到達 した場合は，その波長は赤と緑の中間であり，赤と緑の 2 種の錐体の感度のピークのいずれとも比較的近いので, それらの錐体を同時にある程度興奮させるが，青の錐体 のピークからは遠いので青の錐体はほとんど興畕させな い.この状態は上記のように黄の感覚を生じさせる。 と ころで赤と緑の光が同時に同じ網膜領域に到達しても, やはり赤と緑の錐体が同時に同程度興奮し, 青の錐体が ほとんど興奮しない。この状態は, 上記の黄の光によっ て生じる興奮状態と同じであり,やはり黄の感覚が生じ る.これが前述のように, 赤と緑の混色により黄を感じ る理由であると説明される. また, 赤, 緑, 青の 3 種の 錐体が同時に同程度興奮する場合は白の感覚が生じる。 この状態は太陽光のように可視範囲のすべての波長を均 等に含んだ光によっても生じうるし, 赤, 緑, 青の単色 光が同時に眼に到達しても生じる。これが赤・緑・青の 混色により白が見えることの理由と説明される.さらに 3 種の錐体が種々の比率で興奮するときには, その比率 に応じてさまざまの色の感覚が生じるとされる。この 3 色説は，混色の説明にとくに適した説である.

\section{2 反対色説}

反対色説では, 赤, 黄, 緑, 青, 白, 黒がそれぞれ工 ニークな色で, その感覚の中に他の感覚が混在していな いことを重視する，たとえば，黄は，赤と緑の混色で生 じはするが, 私たちが経験する黄の感覚の中には, 赤味 も緑味もまったく含まれていない,また，赤味と黄味を 同時にもつ橙色とか青味と緑味を同時にもつ青緑色は存 在するが, 赤味と緑味を同時にもつ中間色はないし, 黄 味と青味を同時にもつ中間色はない. この点から, 赤と 緑, 黄と青, 白と黒はとれぞれ対立した色であり, 同じ 過程の反対の極と考える.すな和ち，視覚系内に赤一緑， 黄一青, 白一黒の 3 種の反対色過程を仮定する.この説 では，色順応は，この反対色過程がー方の極の方向にの み続けて進行した状態と説明される，たとえば赤に対す る順応は, 赤一緑過程が赤方向に持続して進行した偏っ た状態であり，同方向にそれ以上の進行をすること（す なわち，さらに赤を知覚すること）はしだいに困難とな り, 逆方向である緑方向への復元（すなわち, 緑の知覚） の生じやすい状態とされる。また色の同時対比は，隣接 領域における反対色過程が偏って進行したため, 当該領 域でもその影響をうけて, 同一過程が逆方向に進みやす
い状態として説明される.ジェームソンとハービッチは, この反対色説で仮定している赤一緑過程と黄一青過程の 基本反応曲線を, 心理学的実験によって求めている.

\section{3 段階説}

今日では，3色説も反対色説もそれぞれ生理学的根拠 をもっている. 3 色説は, 錐体内視物質の分光吸收特性の 測定, ならびに微小電極による錐体内活動電位の記録に よって，錐体レベルで実証されている，一方，反対色説 は網膜中の水平細胞と外側膝状体の電気生理学的研究に より支持されている.したがって，現在では， 3 色説と反 対色説は相対立する学説ではなく, とり扱っているレべ ルが異なるにすぎないと考えられている．錐体レベルで は, 3 色説で仮定されているような過程が生じていて, そ の結果として得られた神経信号がつぎの段階で反対色的 過程に変換されるという, 段階説 stage theory が有力と なっている。（西條論文参照)

\section{5. 色彩の心理的効果}

まず，口絵 4 の a とbを比べて頂きたい．a は通常の 仕方で磁力線の密度分布を色表示したものであり，b は 通常と反対の仕方で色表示したものである。目は自然に 赤の部分に向く，a のように，赫が磁力線の密度が高い 部分を表し, 橙, 黄と次第に密度が低くなり, 青がもっ とも密度が低いことは，説明がなくても，直観的にわか るし, 自然に受け入れられるであろう。しかし, bのよう な表示は，不自然である。 また口絵 5 の交通の混雑状態 を示したものであるが，aのように赤が混んで青がすい た道路を示す方が自然で, b の逆は不自然である.色で温 度を示す場合なら, 赤が高温, 青が低温, 橙, 黄, 緑が 色相順にその間に入るのが極めて自然である. 色表示は， 地下鉄の路線図のように単に区分けの記号に使われるこ ともあるが，色は単なる記号以上の意味をもっている。

たとえば，暖色，寒色といわれるように色は温度感覚 や「暖かさ」、「冷たさ」で象徵されるような感情の問題 とも関連する. また進出色一後退色とよばれて, 色は距 離感覚にも影響を与えるし, 物の大きさ, 重さの判断に も影響する。

このような色の心理的効果は個人の主観的体験に現れ るだけでなく，客観的方法により得られた科学的デー夕 としても把えることができる.

\section{1 暖色と寒色}

結論から先に述べれば，視覚的に色を与えただけで， 温度判断を求めれば, 通常いわれているように, 赤, 黄 などの長波長色が暖かく, 青を中心とした短波長色が冷 たく感じられることは，多くの実験によりたしかめられ ているが, ある温度の物体や液体に手をふれ, 皮膚感覚 的にも温度を感じるとともに視覚によりその物体や液体 の色を感じるという実験事態では, 結果がまちまちとな る.

筆者らは, 言語心理学研究や市場調査などに用いられ 
ているオズグッドのセマンティック・ディファレンシャ ル法（SD 法）（柳瀬論文参照）を用いて行った研究の一 部としてこの問題をとりあげた。 その結果では, 日・米・ 台湾いずれの地域の人々も赫がもっとも温く, 青がもっ とも冷く, その間, 色相順に温さ, 冷さを感じているこ とが示された。

\section{2 進出色と後退色}

色によって観察者に向かって進出して見えるものと， 後退して見えるもののあることは，いろいろの分野の学 者によって研究がなされてきた。 その結果, 一般に長波 長の色, 赤, 橙, 黄などは進出し, 短波長の青, 董など は後退することが報告された。波長の差による座折率の 差異による, 眼球内の色収差がこの現象の原因と考える 人が多かった。その中には, その水晶体の調節（目のレ ンズである水晶体の変形による焦点距離の変化）におよ ほす影響を媒介とするものと，両眼視差におよ涩す影響 を媒介とするものと 2 説があるが，色の感覚と関係なし に,レンズ系としての眼球内部の物理的現象として説明 する点は共通している。

筆者らが小空を通して見える色彩面（その垂直の緑が 見えている）ともう一つの小空を通して見える垂直棒と が, 同じ見かけの距離になるように被験者に調整しても らつた実験結果では, 赤が一番近く, 青が一番遠く, そ の間, 色相順に見かけの距離が変化することが, 見事に 示された. しかし，色覚異常者に被験者になってもらう と, 色の弁別が困難な赤一黄一緑の間では見かけの距離 の差がなく(赤と青との距離感の差は明確), 色の感覚と
関係しないという色収差説の予想とは異なっていた。

\section{3 膨張色と収縮色}

膨張色と収縮色という言葉があり, ときどき赤は青よ り大きく見えるなど，暖色一寒色と見かけの大きさが関 係しているかのような記述が見られるが, 明確な実験的 根拠はないようである.

抽象画の先駆者といわれるカンデンスキーが, 黄と青 とを対立させて, それぞれ進出・後退運動ととも, 遠心 的運動と求心的運動を含むとの見解を述べたことが, 一 般に普及しているためかもしれない。しかし，これは， 彼がたまたま，黄と青という暖色一寒色の対立とともに， 明暗の対立を含んだ色を代表として選んだために混乱し たのであろうが, 明度の等しい赤と青と比較しても見か けの大きさの差はほとんど見出せない.

筆者らが, 被験者たちに種々の色相や明度の充実円の 見かけの大きさを, 種々の直径をもつ白地に黒の輪郭円 と比較してもらった結果においても, 明度が高い充実円 ほど大きく見える傾向は影著に現れたが, 明度が等しく 色相だけ異るものの間には見かけの大きさの差異はほと んど見出せなかった。

このような色彩の効果は, 個人的な経験にもとづく連 想などでは説明できない万人共通の傾向であり, 色彩の 感情効果, 色のイメージ, シンボル性などの基礎となっ ているのと考光られる(柳瀬論文参照).

\section{参考文献}

大山正: 「色彩心理学入門』(中公新書 1169) 中央公論社, 1994 


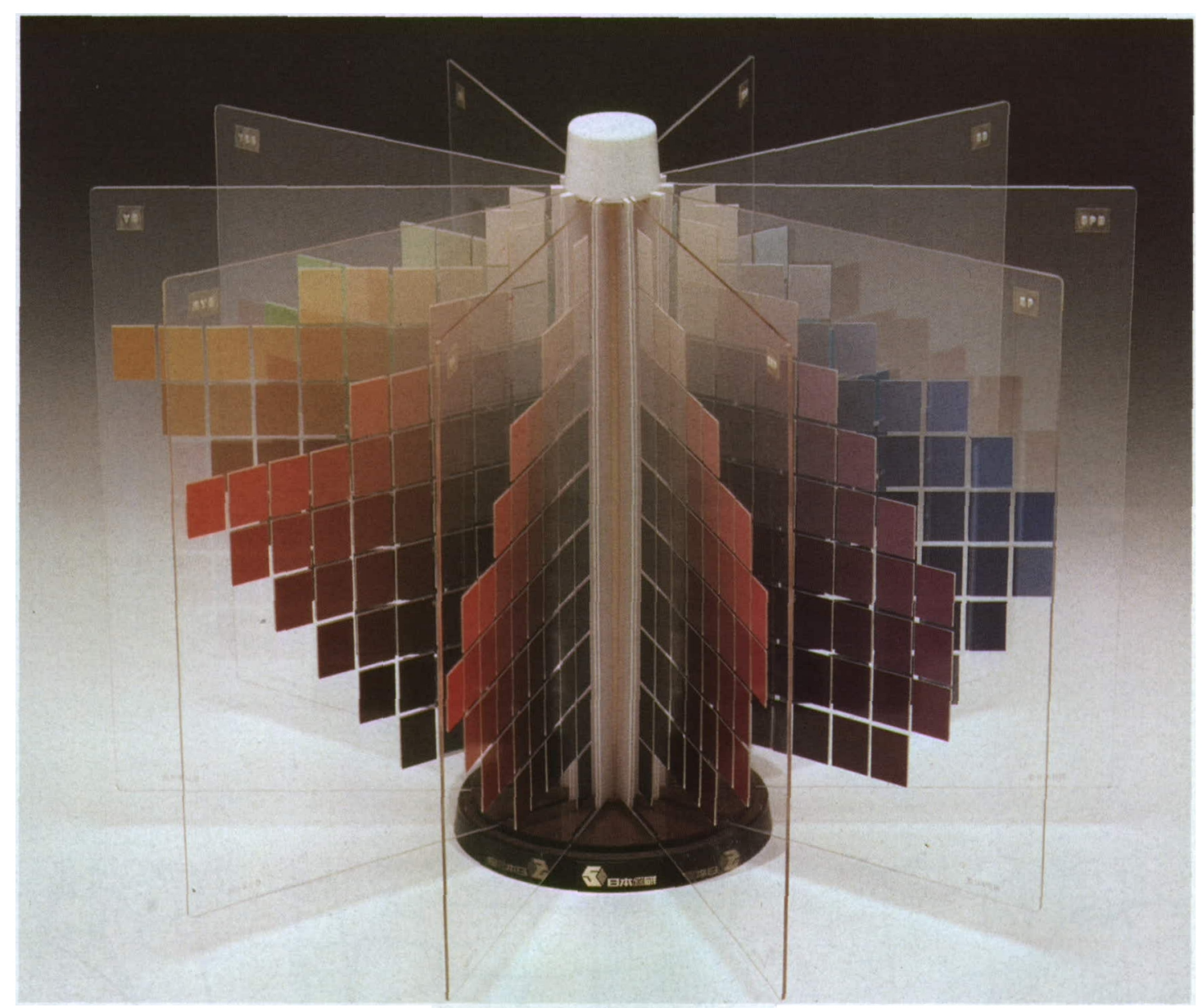

ロ絵 1 マンセルの色立体

（日本色研事業(侏提供）

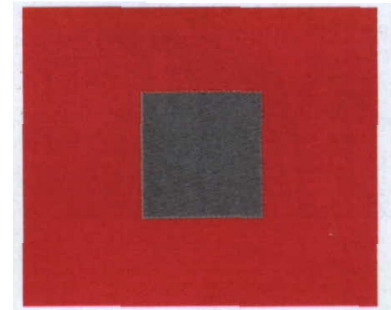

口絵 2 色の対比.

同じ灰色が色に囲まれると反対色を帯び て見える

(中央公論社刊 色彩心理学入門より)
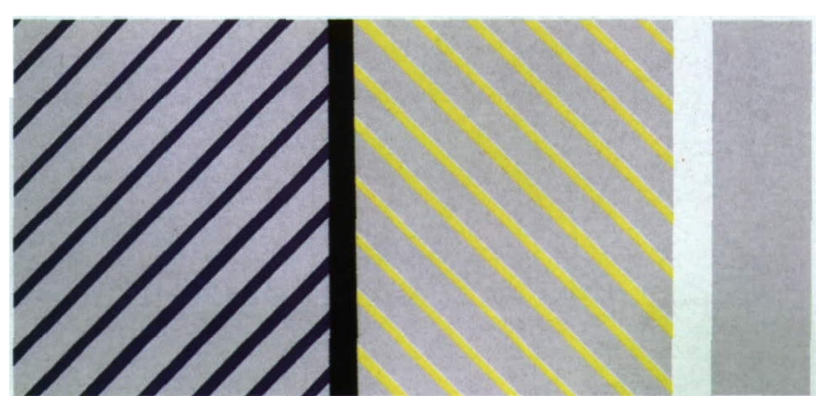

口絵 3 色の同化.

右端と同じ灰色が色の縞にはさまれると 色づいて見える

(中央公論社刊 色彩心理学入門より) 


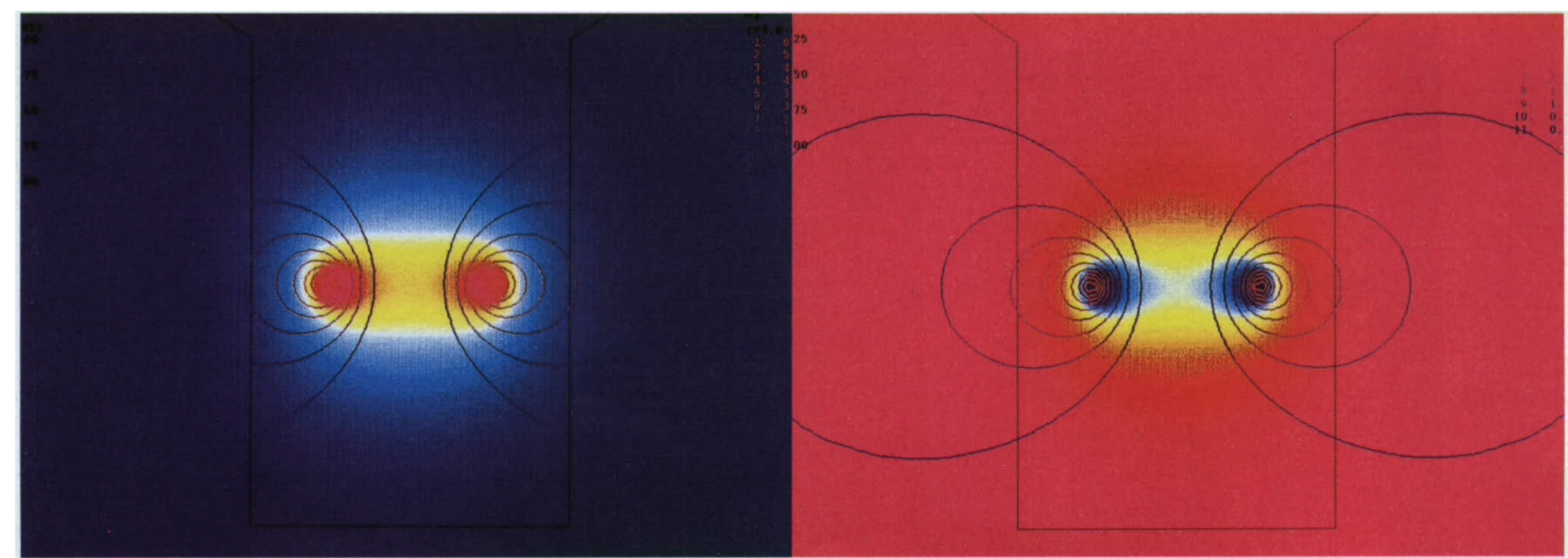

(a) ライン等高線表示: 磁力線

カラーグラディエーション: 磁束密度分布（正常）

(b) ライン等高線表示: 磁力線

カラーグラディエーション: 磁束密度分布（反転）

口絵 4 円筒コイルの作る磁束密度分布（計算結果）

(侏立製作所日立研究所提供)

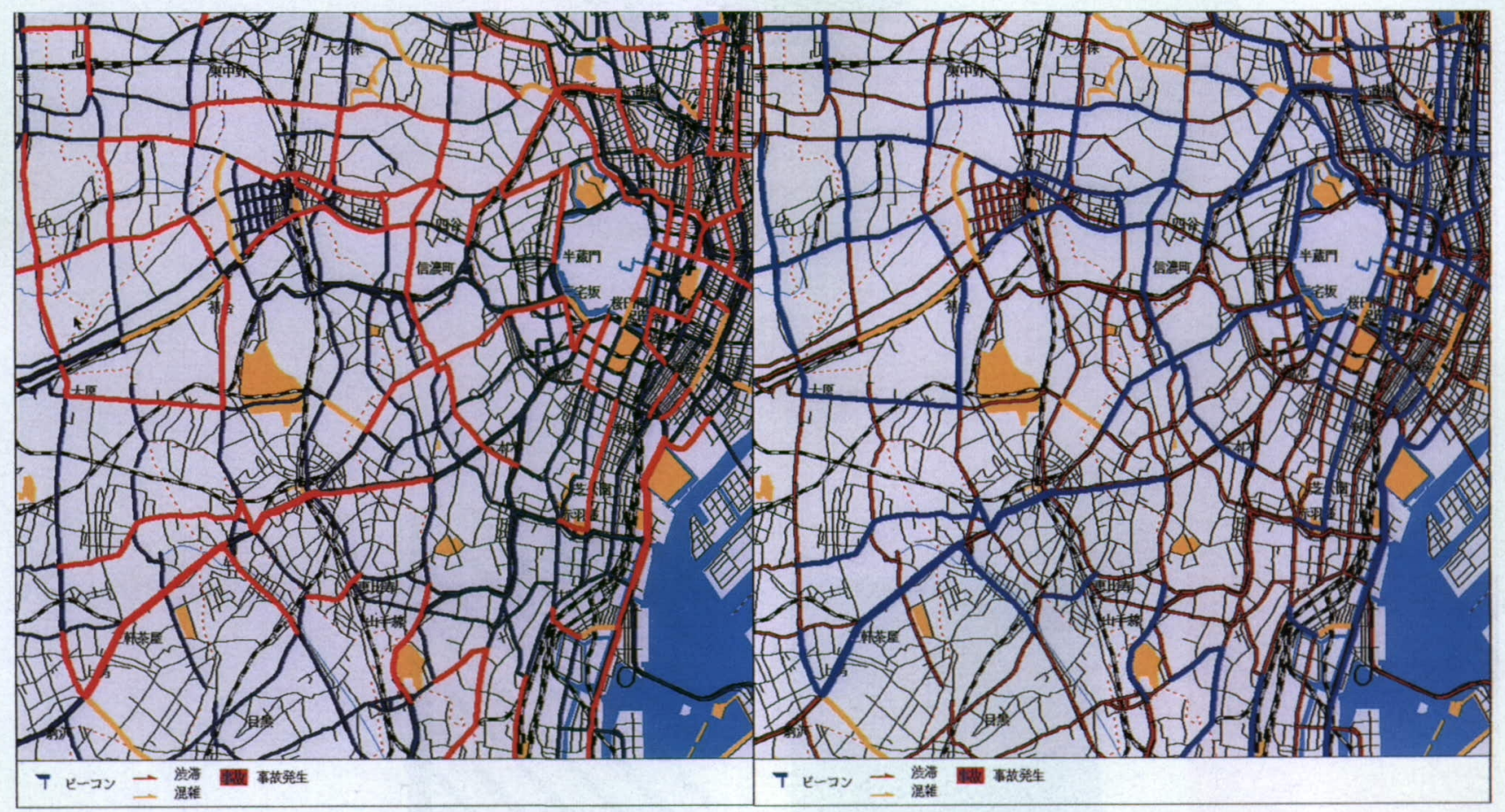

(a) 通常表示 青, 橙, 赤の順で混んでいるところが赤

(b) 逆転表示 すいているところが赤

口絵 5 交通情報

(森)日立製作所日立研究所提供) 